$$
\text { سفارش ش ان جي شرعي حيثيت }
$$

\title{
RECOMMENDATION AND ITS LEGAL STATUS IN ISLAMIC SHAREA
}

\author{
باكتر بثير احمد رند" \\ DOI: 10.29370/siarj/issue3ar5 \\ Link: https://doi.org/10.29370/siarj/issue3ar5
}

\begin{abstract}
:
Human needs are so varied and interdependent that one cannot live in isolation. The needs are only fulfilled with the mutual cooperation of people within a society. Since Man lives in a community therefore he has certain obligations and responsibilities of his community. One of his obligations is to morally support people. Among his moral responsibilities one is to listen/accept the recommendation of a needy person. But it is generally observed that people go astray in recommendations. They bring and accept illegal recommendations and put certain pressures, forces and personal sources. In case of denial, anguish and fury is created. While following such illegal recommendation, incompetence and injustice is spread which lead distress and dissonance in the whole society. In this view, the actual purpose of recommendation has not been properly understood. Islam is a religion which guides humanity at every stage. It gives crystal clear guidelines for pursuing and accepting any recommendation. This paper discusses in detail what is recommendation, its different forms and in which matters recommendation is allowed to accepted/reject.
\end{abstract}

KEYWORDS: Recommendation, Legal, Illegal Prescribed Punishments , Crime, Witness, Advice

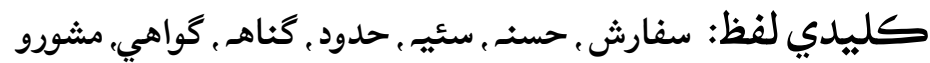

$$
\begin{aligned}
& \text { كويـ انسان اكيلو نتو رهي سگهي.ان كري جو سندس گهرجون ايتريون ت خهيطيون }
\end{aligned}
$$

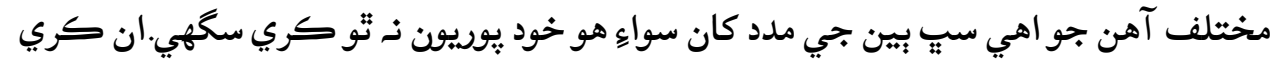

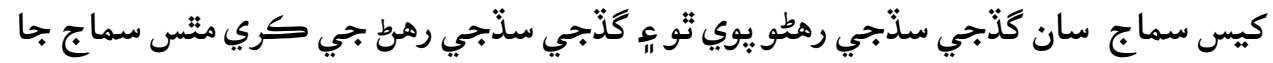

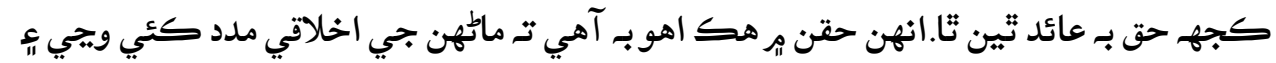

$$
\begin{aligned}
& \text { * ايسوشيئيت يروفيسرشعب اسلامك كلجربسنت يونيورسني جامشور برقي يتو: : } \\
& \text { bashir_rind2006@yahoo.com }
\end{aligned}
$$


اخلاقي مدد جي هك صورت كنهن حاجتمند جي سفارش كرط يا ان جي حق ير كيل كيل

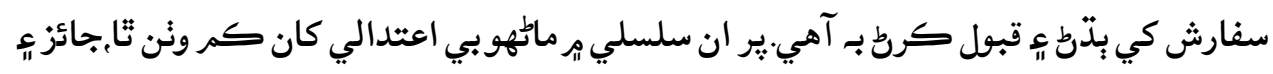

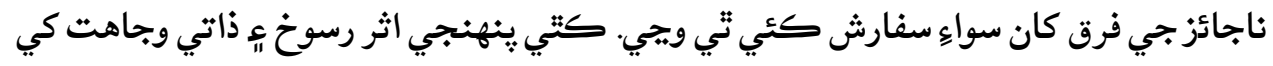

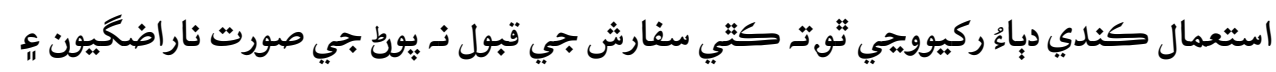

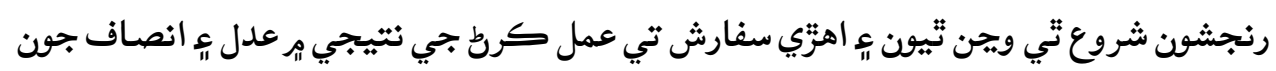

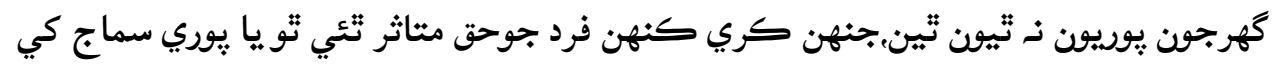

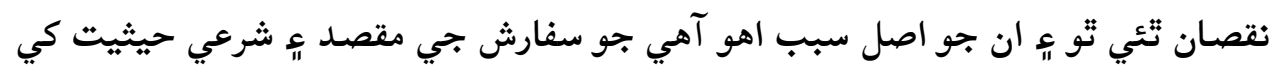

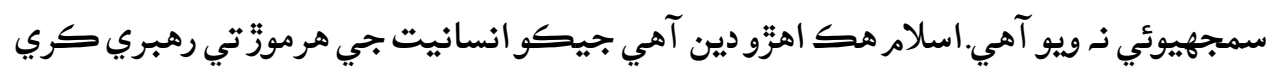

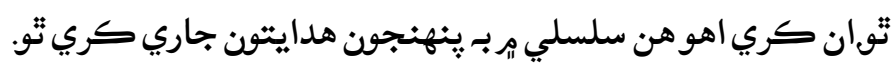

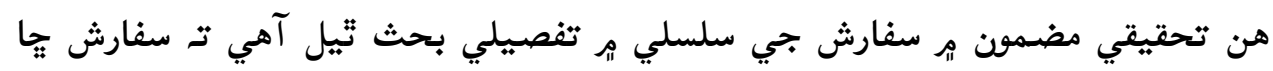

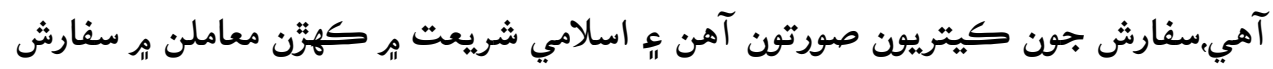

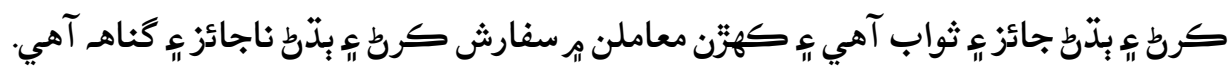

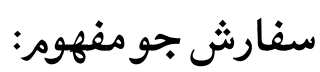

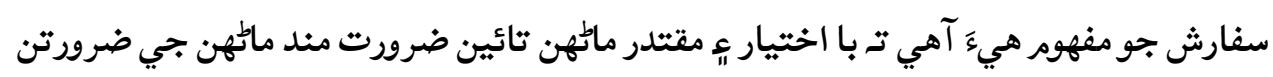

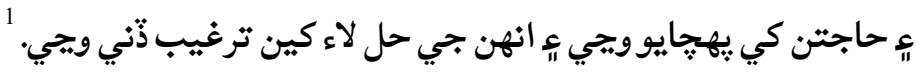

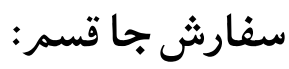

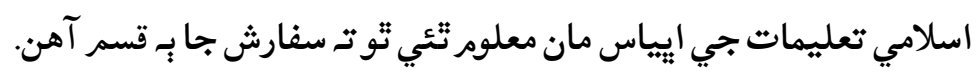
1. شفاعت حسن (نيك ئ جائز سفارش) مانيات

2. شفاعت سيئة(بري ي ناجائز سفارش) هـ

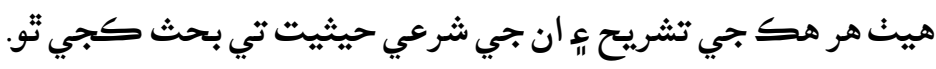
نيك ئ جائزسفارش:

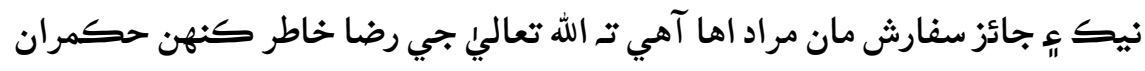

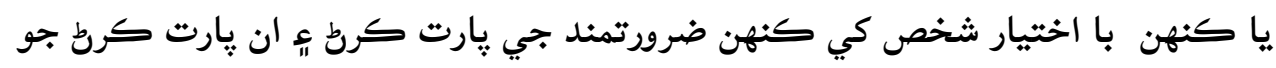

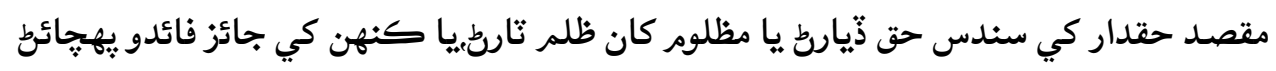

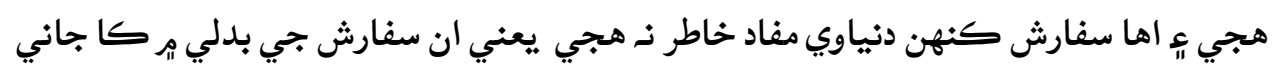

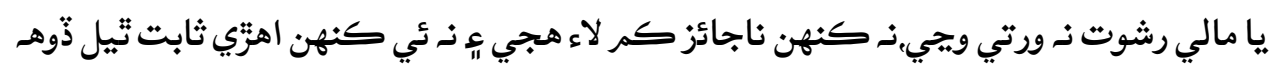

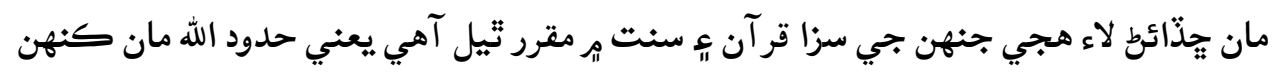




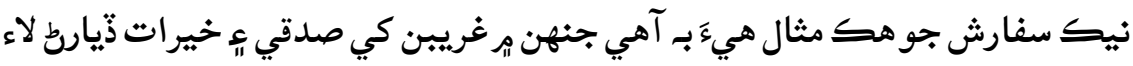

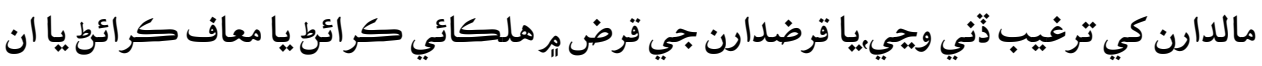

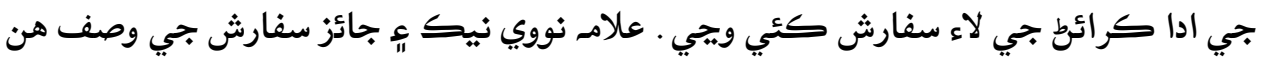

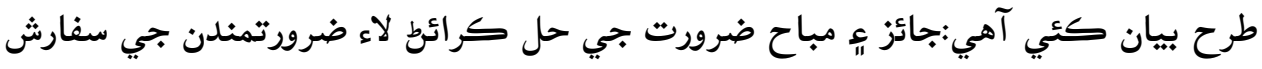

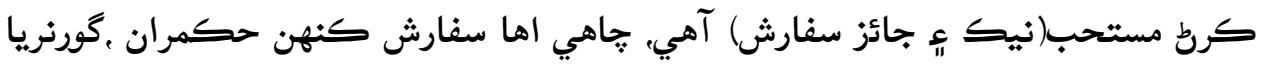
كنهن سركاري كارندي وت كئي ويجي يا كنهن عام ماطهو وت كئي ويجي.اهزي طرح

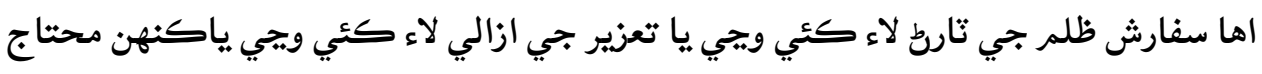

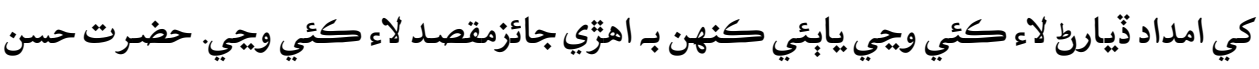

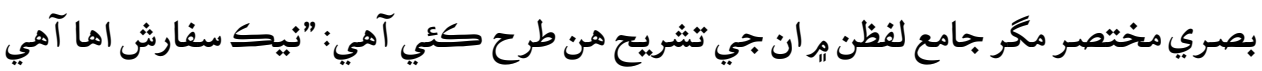

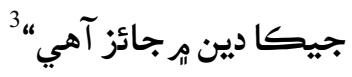
نيك سفارش مستحب عمل :

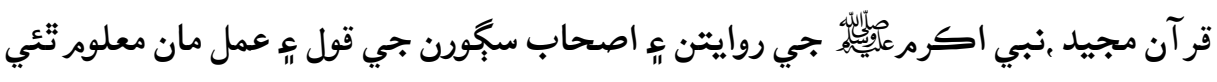

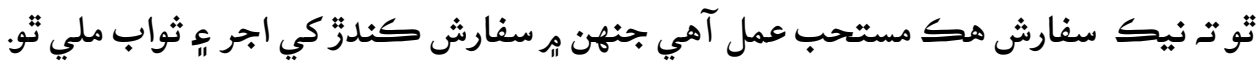
هيث ان جا دلائل ذكر كجن تنا. قر آني آيت ئ تفسبر:

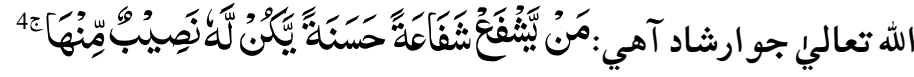
"جيكو نيك سفارش كندو ان كي سفارش جي كري ثواب جوهك حصو ملندو." حضرت

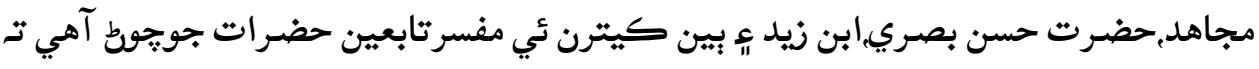

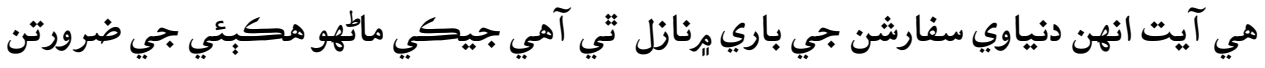

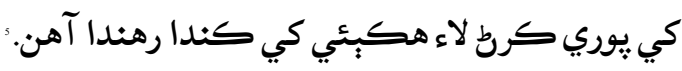
مفني محمد شفيع عثماني ان آيت جي تثريح كندي فرمايو:جيكو شخص سئ كنهن جي

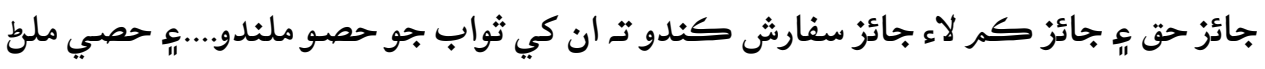
جو مطلب اهو آهي تـ جنهن شخص كي سفارش كئي وئي آهي اهو جذّهن ان مظلوم ري محروم

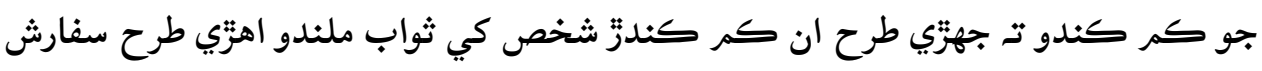

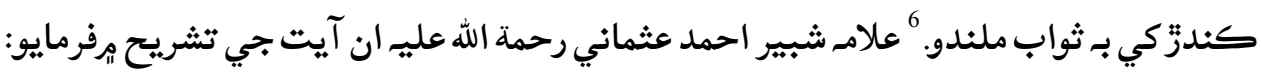
جيكذّن كو شخص كنهن محتاج جي سفارش كري ان كي دولتمند كان كجه ذيّاري 


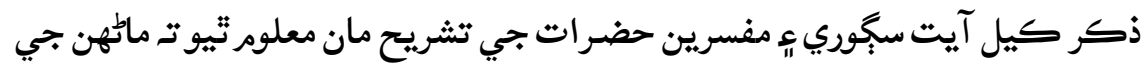

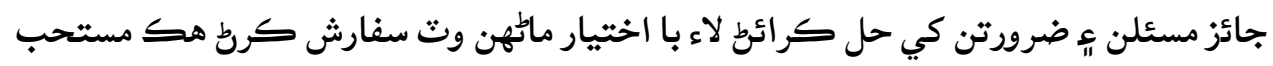

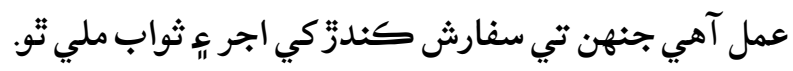

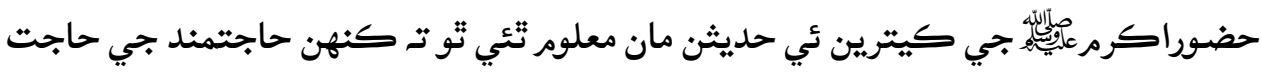

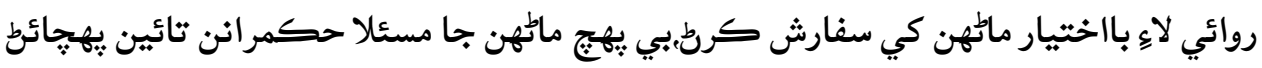

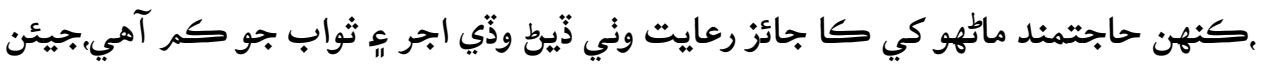

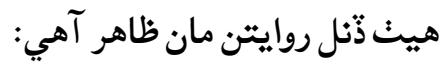

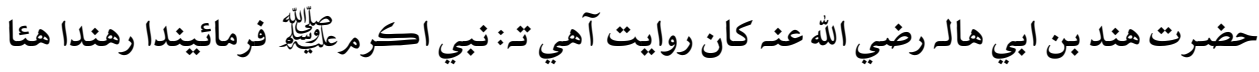

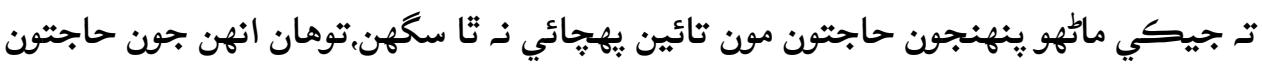

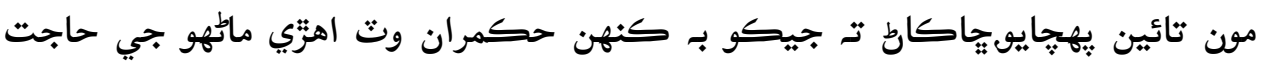

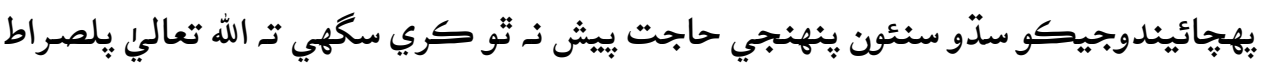

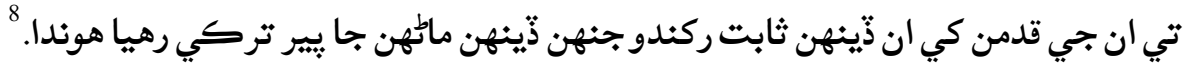

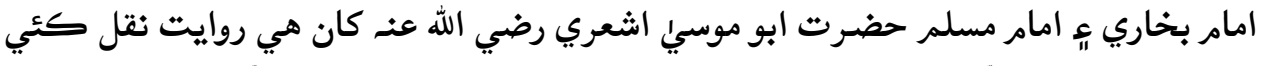

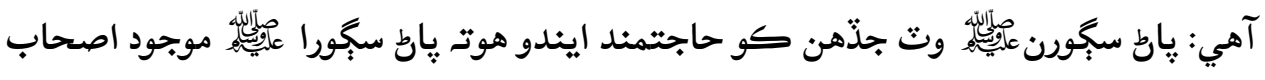

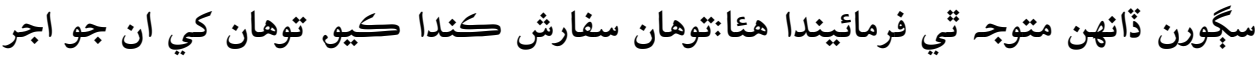

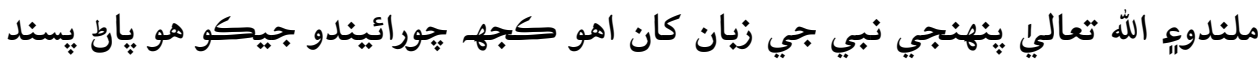
فرمائيندو. 9

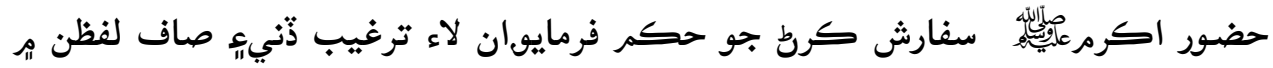

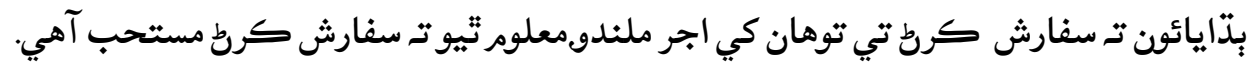

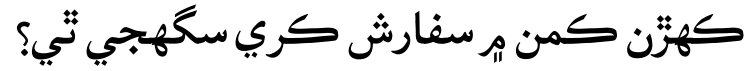

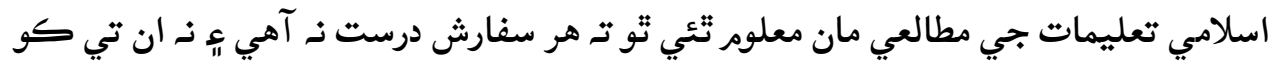

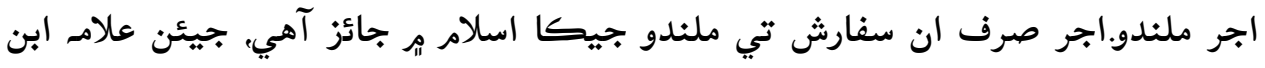

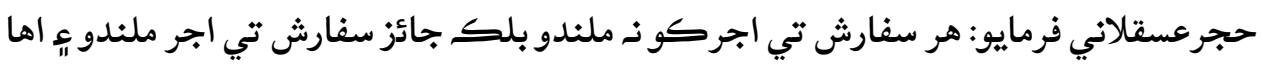

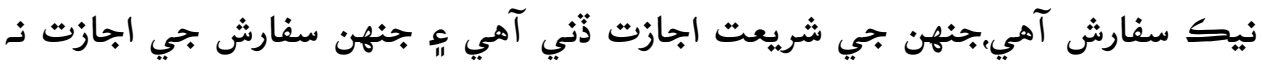

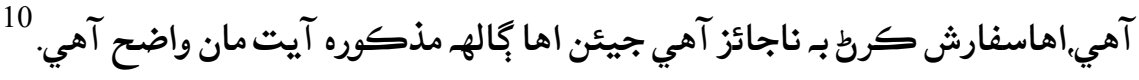




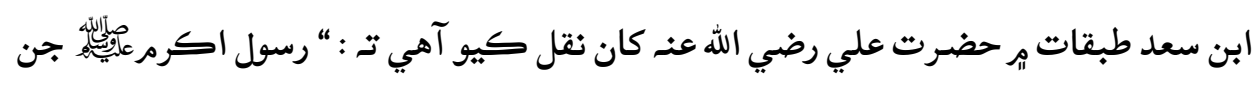

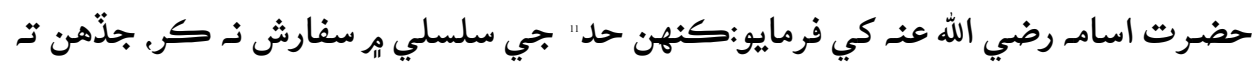

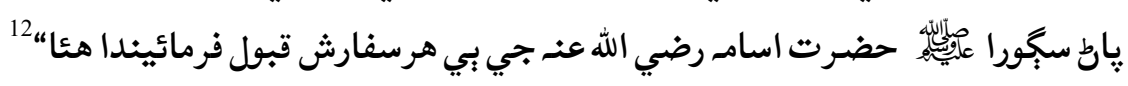

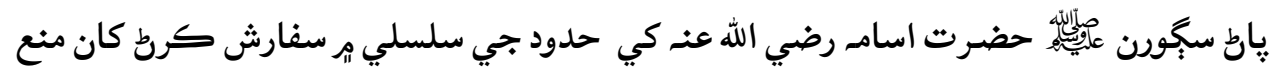

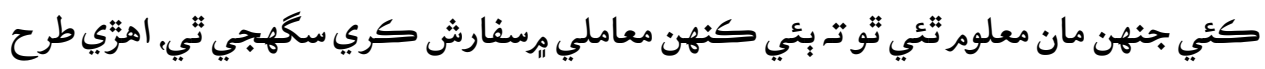

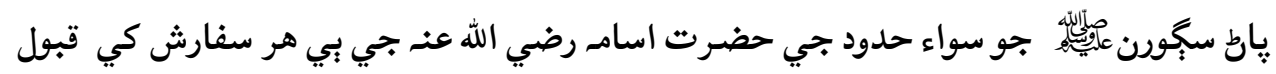

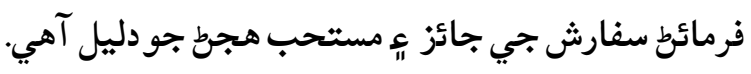

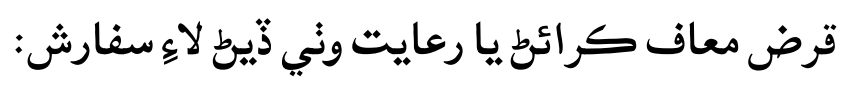

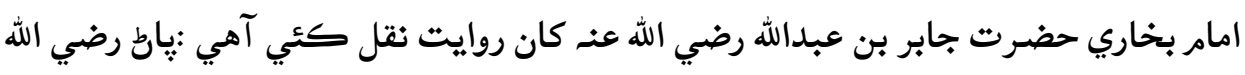

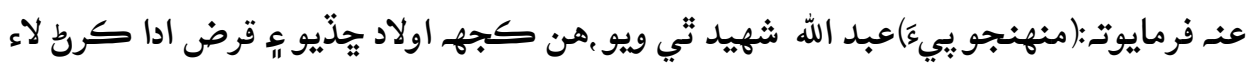

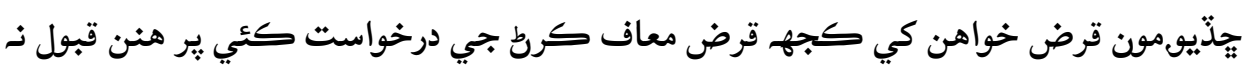

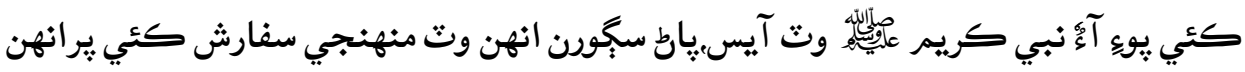

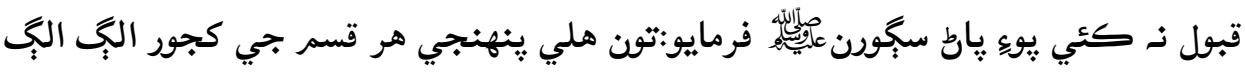

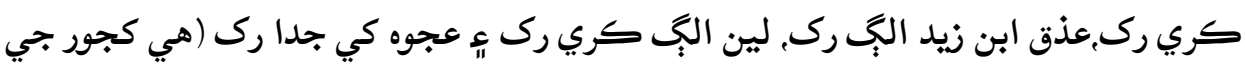

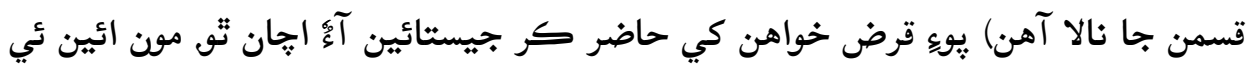

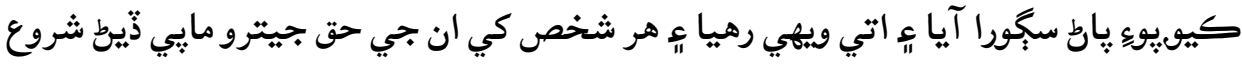

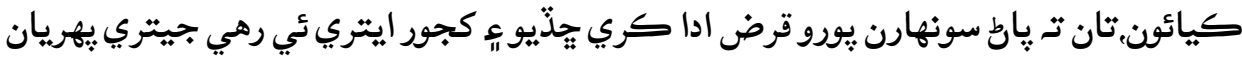

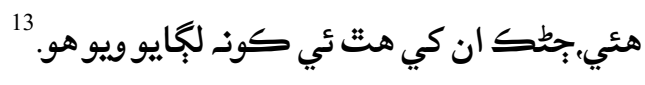

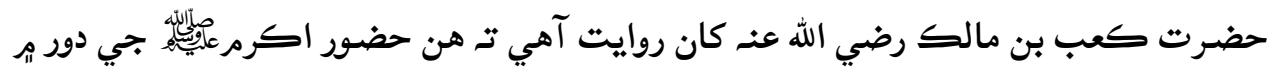

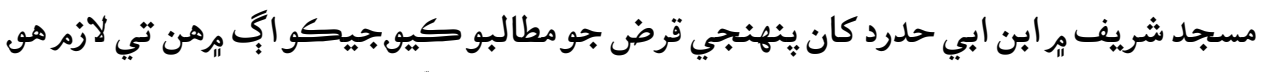

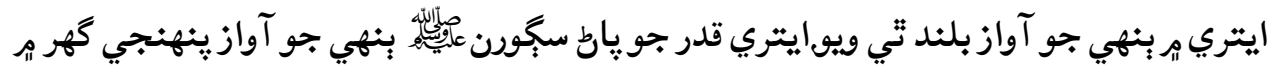

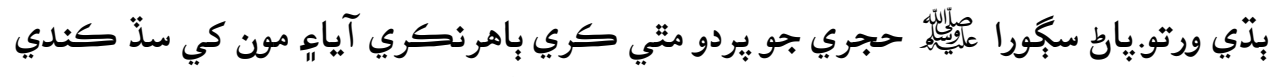

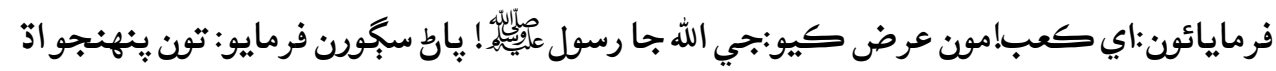

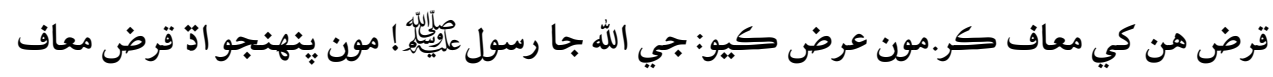

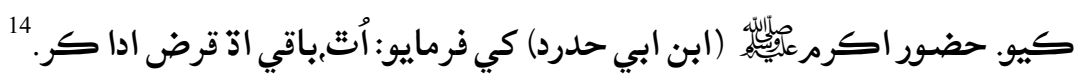

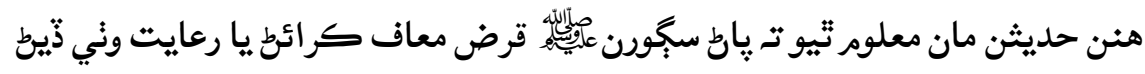

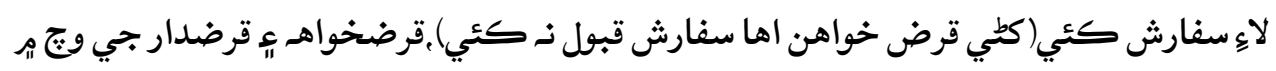




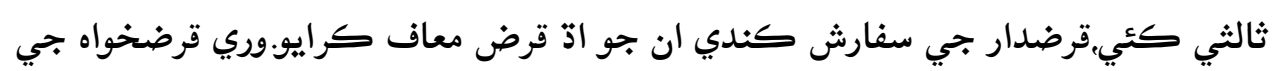

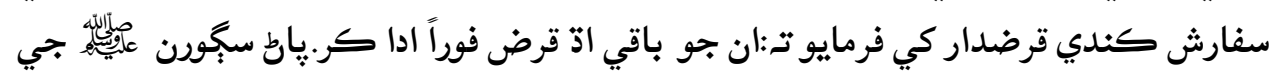

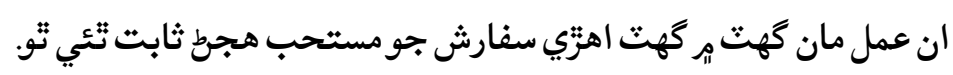

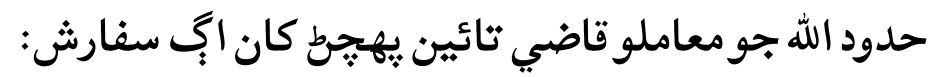

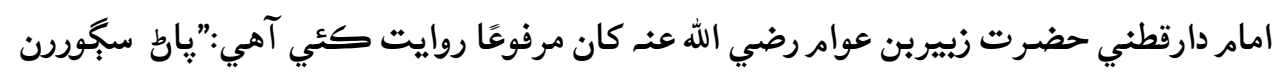

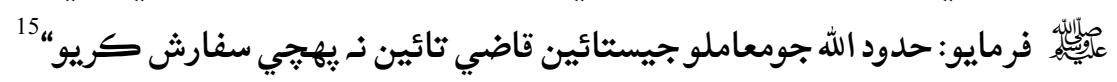

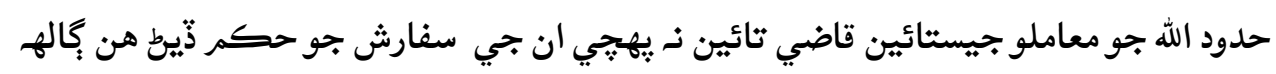

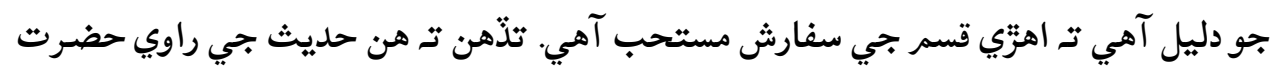

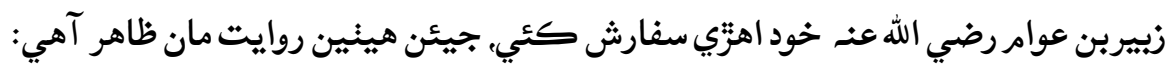

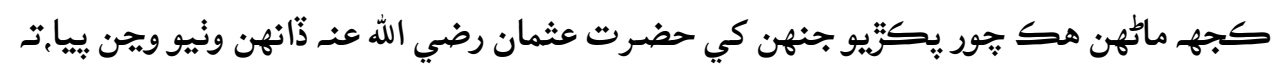

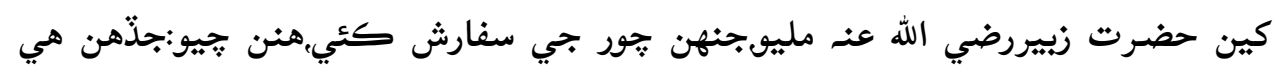

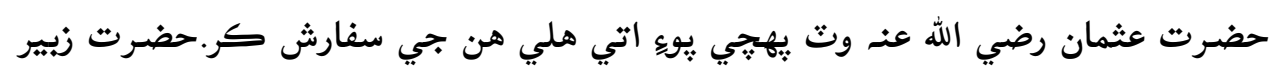

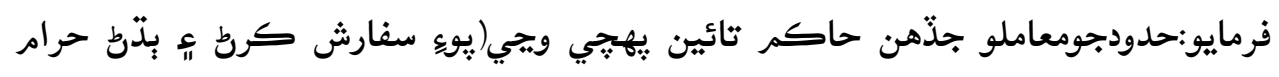

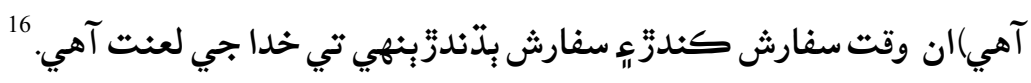

$$
\text { تعزيرات مر سفارث: }
$$

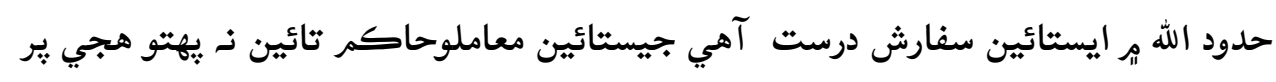

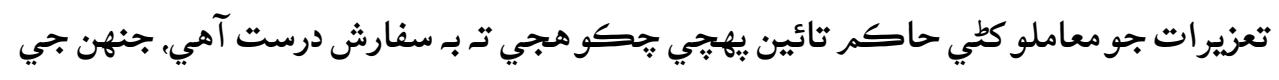

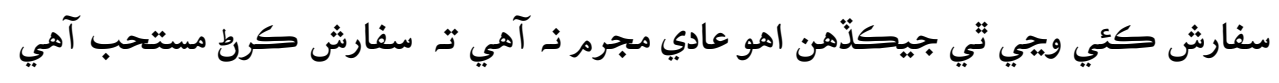

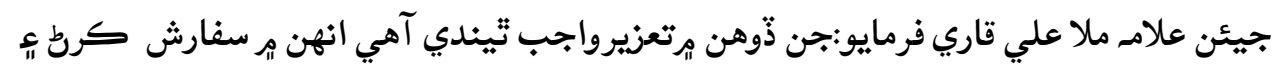

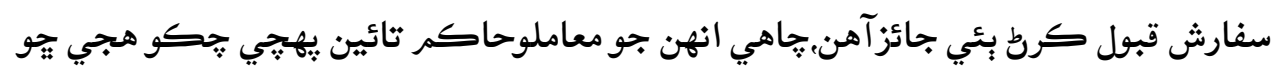

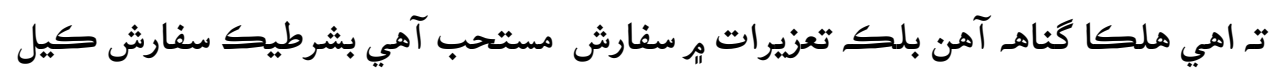

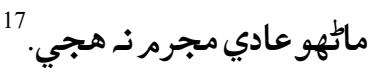

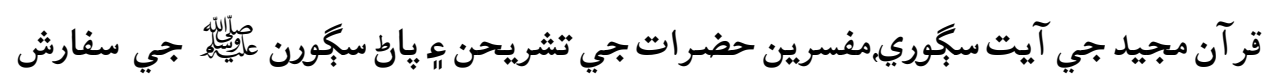

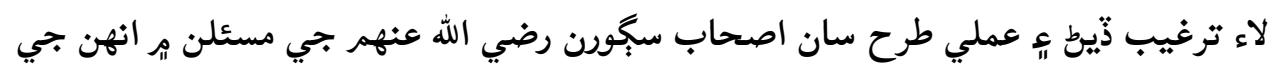

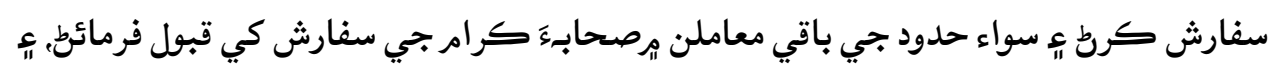

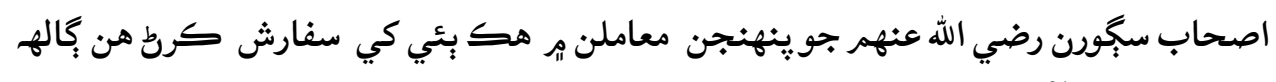

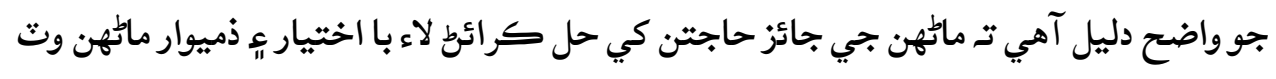

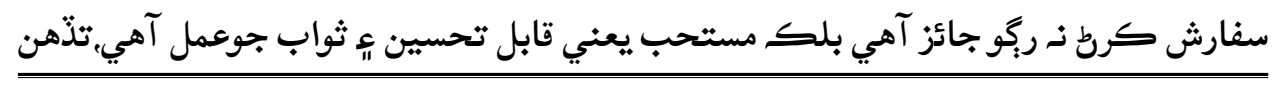




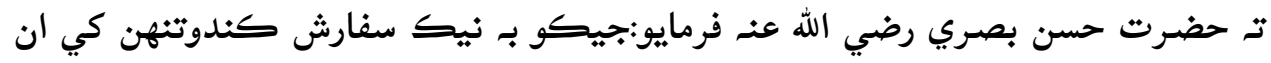

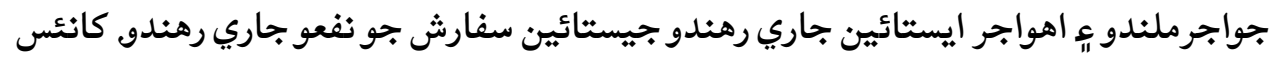

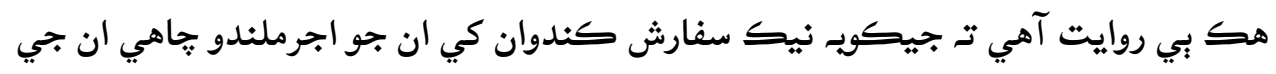

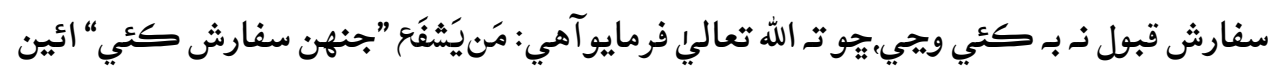

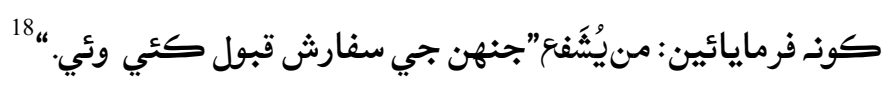

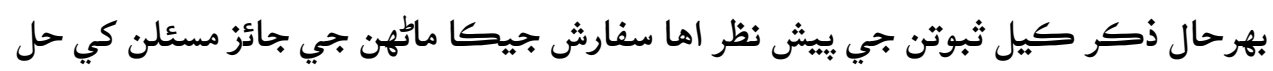

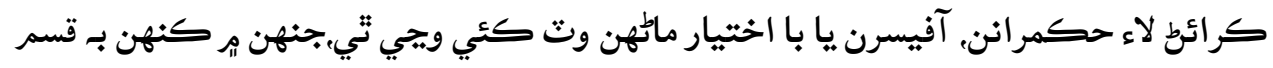

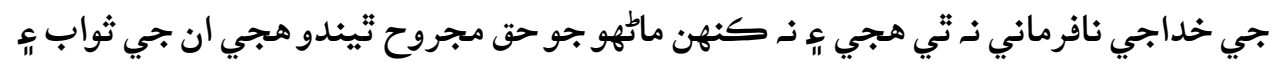

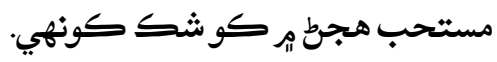

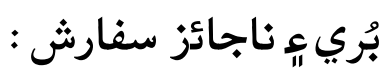

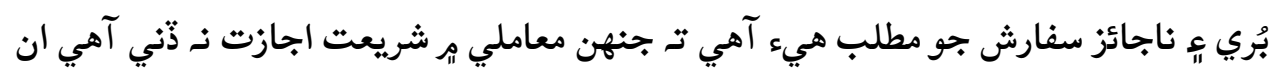

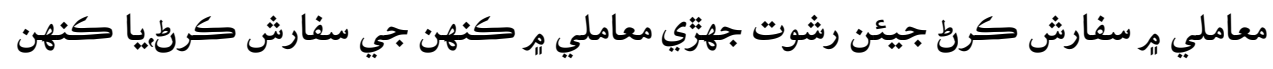

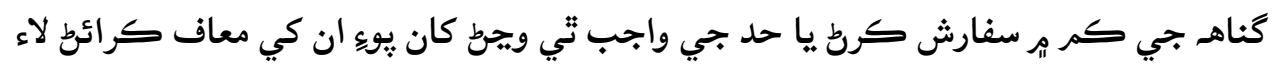

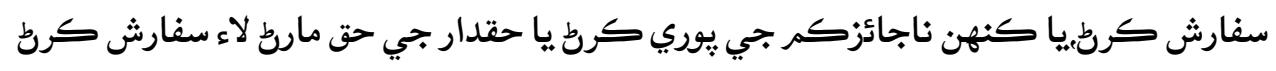

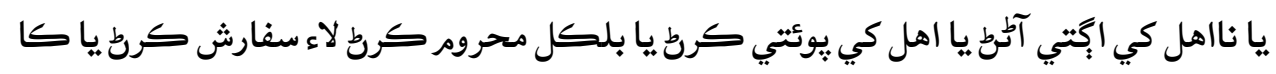

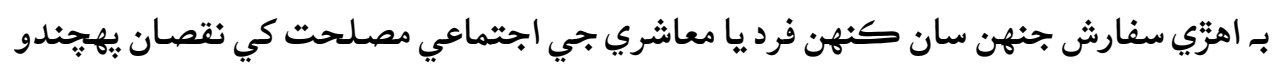

هيث ان جا دلائل ذكر كجن تا:

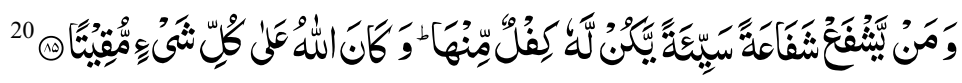

$$
\text { قرآني آيت }
$$

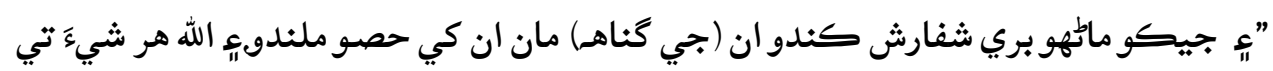

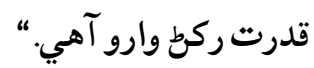

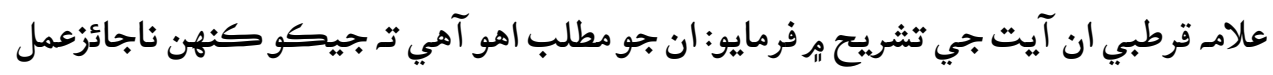

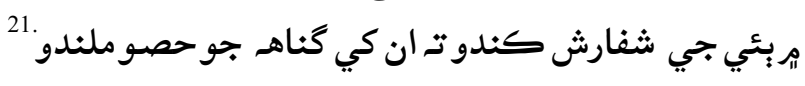

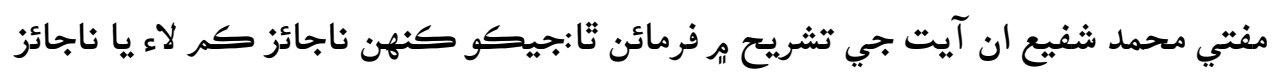

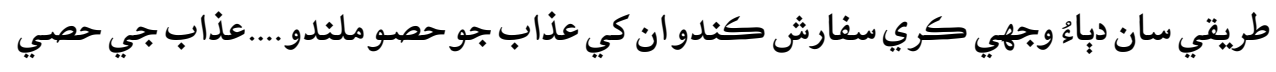

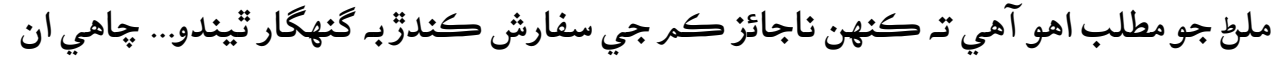




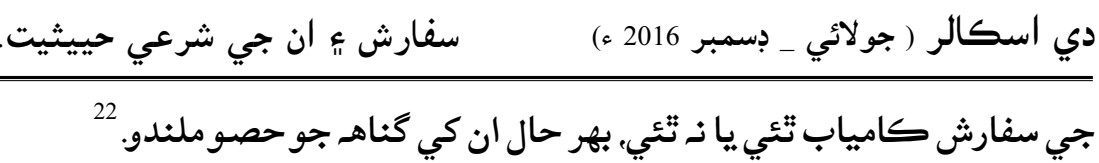

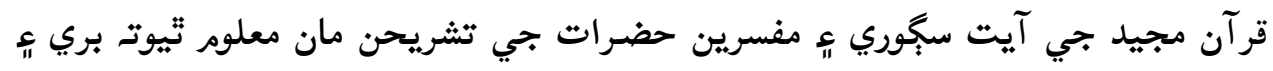

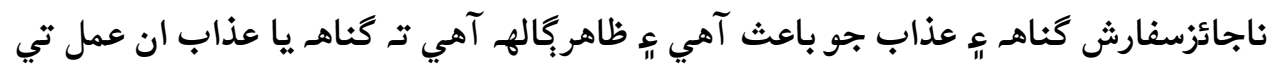

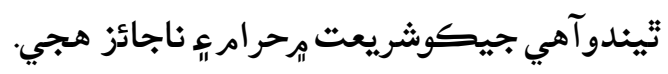
احاديث:

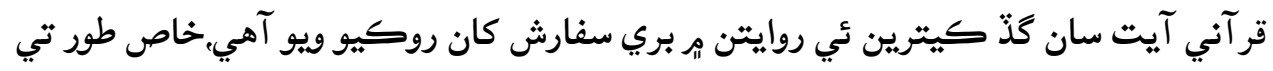

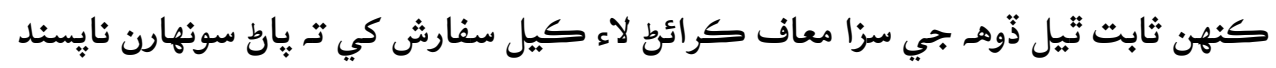

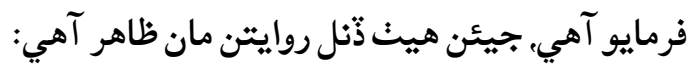

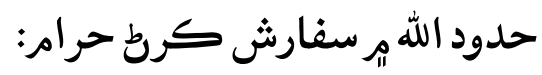

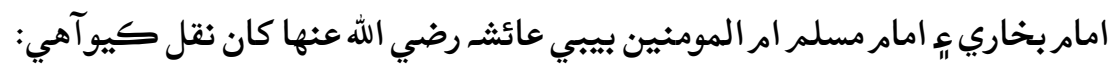

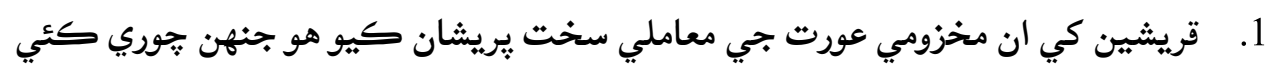

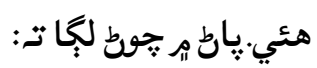

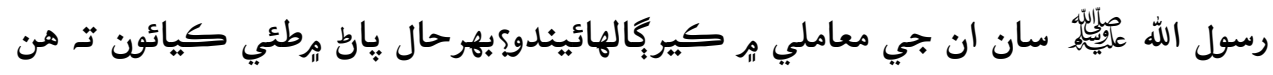

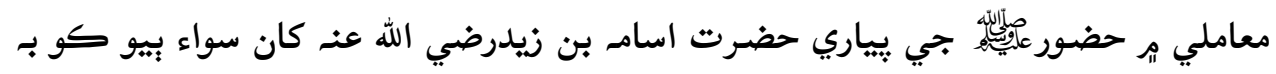

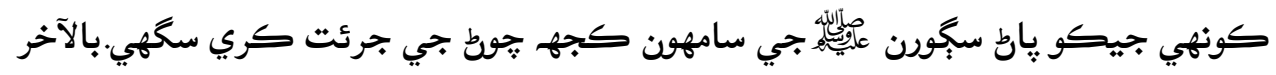

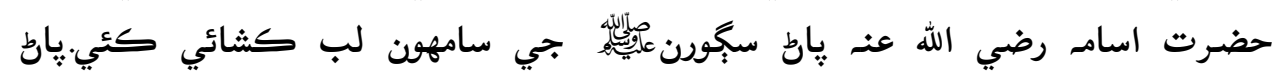

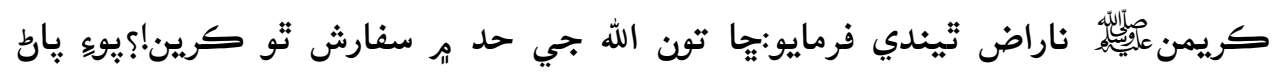

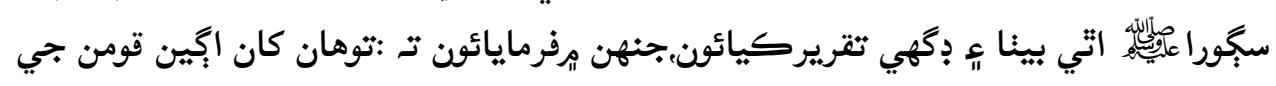

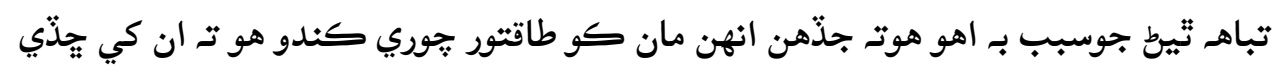

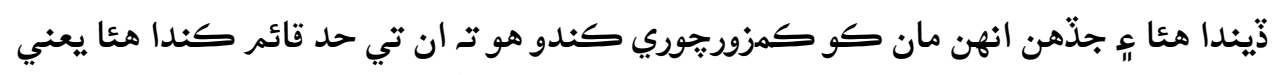

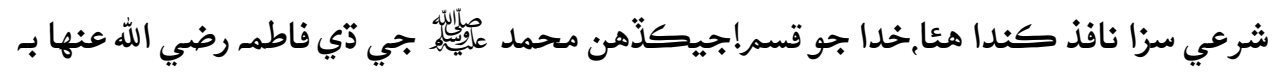

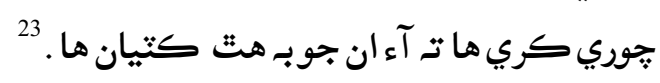

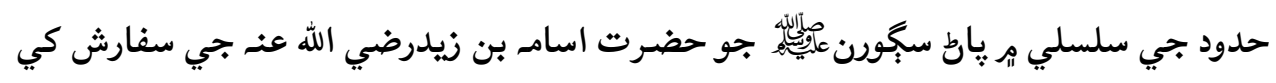

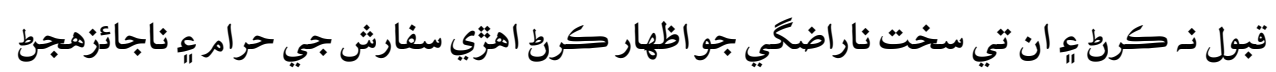
جودليل آهي. 2. امار احمد ئ ابو داؤد حضرت عبدالله بن عمررضي الله عنهما كان روايت كئي آهي.جنهن

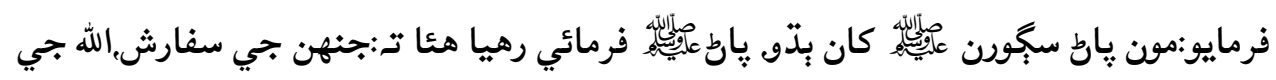




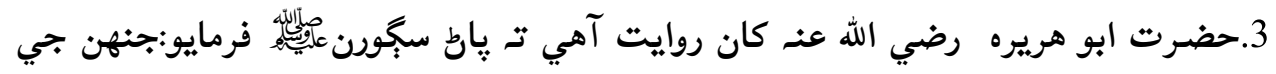

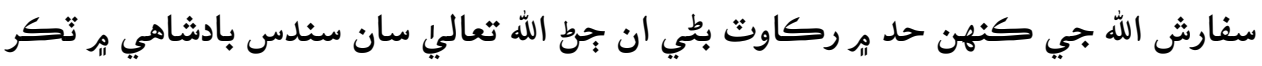

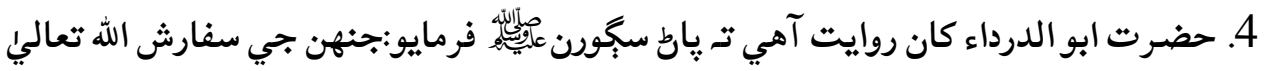

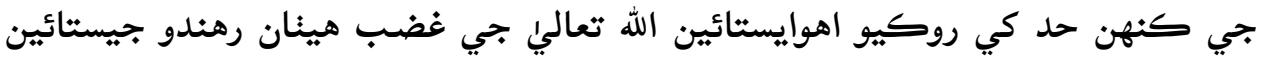
ينهنجي سفارش كان بازن ايندو.

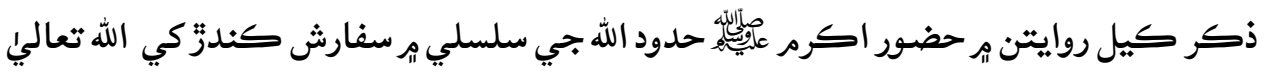

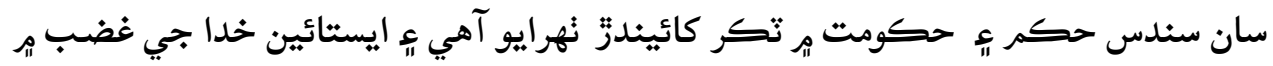

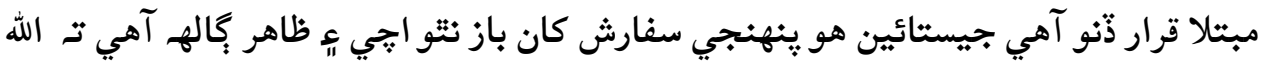

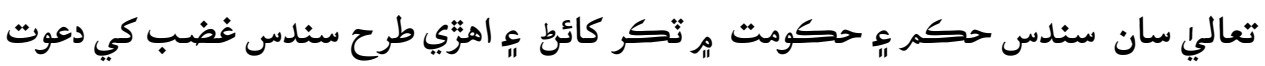

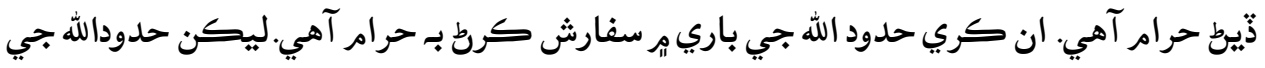

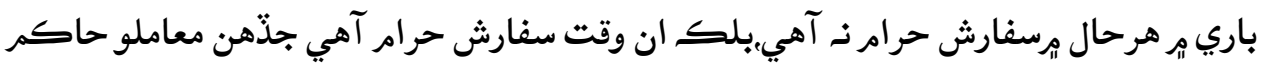

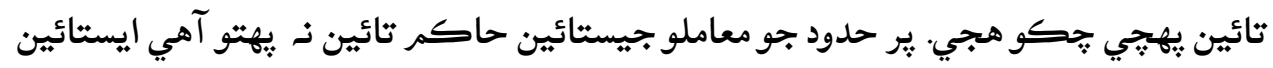

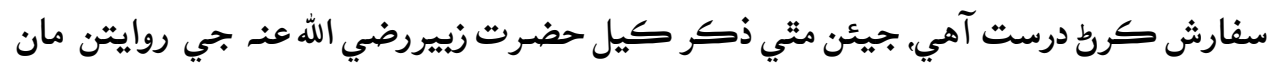

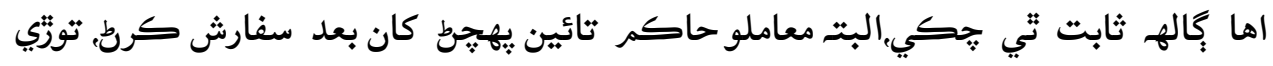

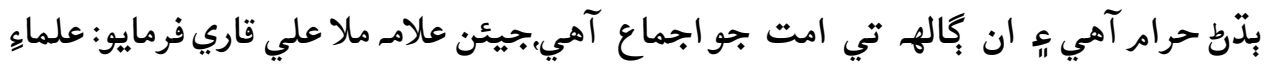

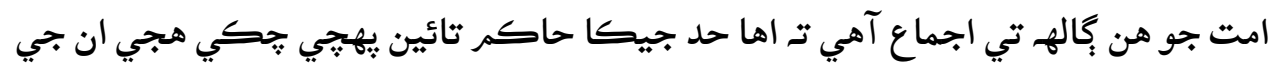

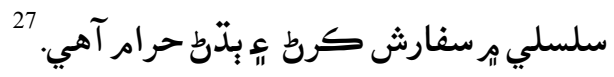
ظلمرزيادتي ي حق جي خلاف سفارش:

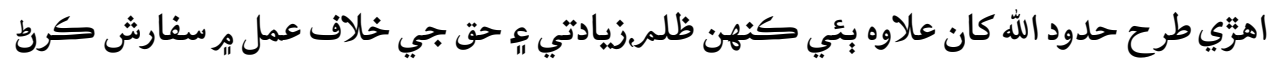

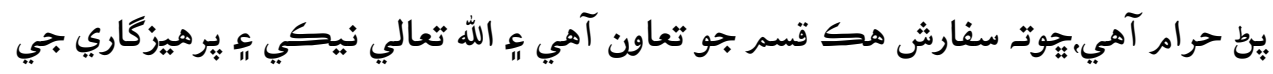

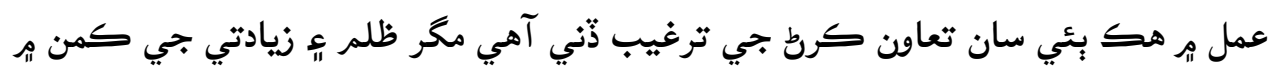

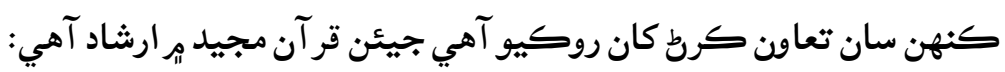
28

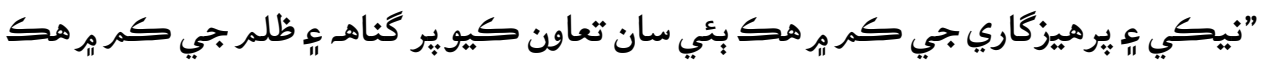

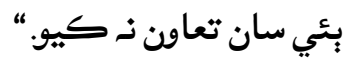


هن آيت سجوري ير ظلم ي زيادتي واري كم ير كنهن سان تعاون كرط كان صاف لفظن يـ

$$
\text { روكيو ويو آهي. }
$$

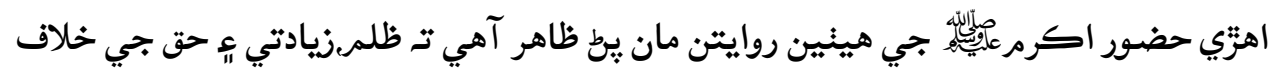

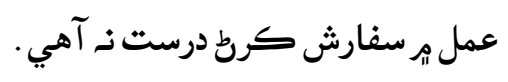

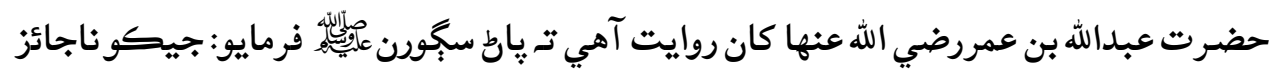

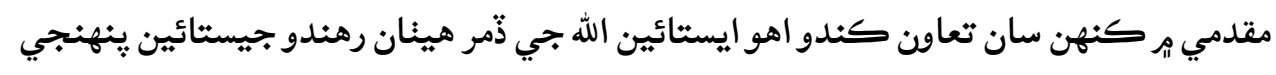
تعاون كان بازن ايندو. 29

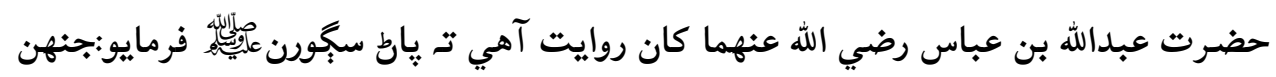

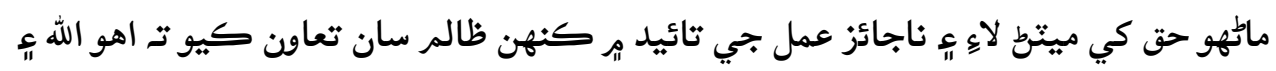

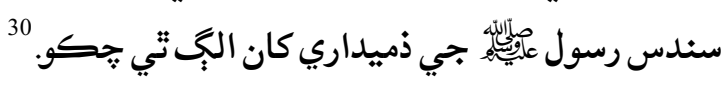

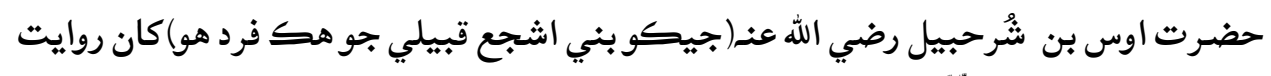

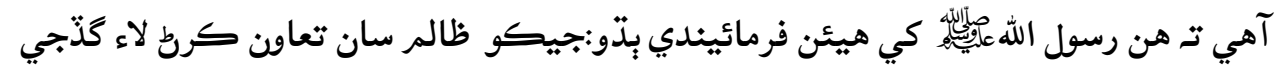

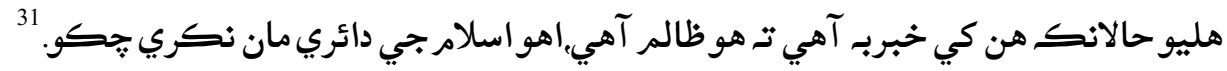

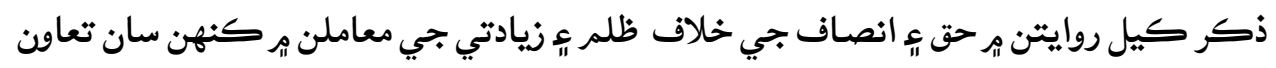

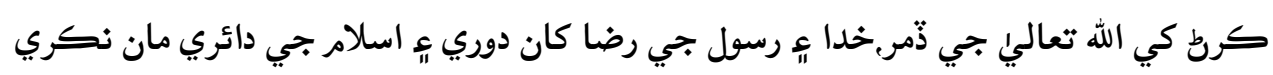

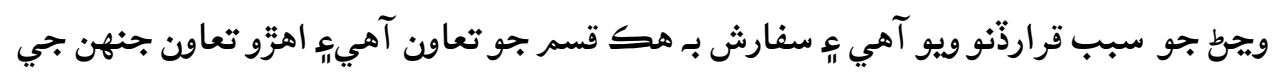

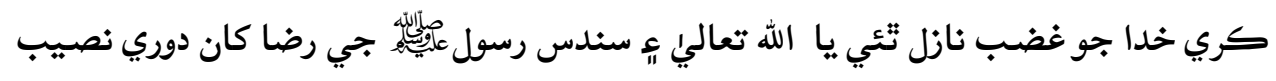

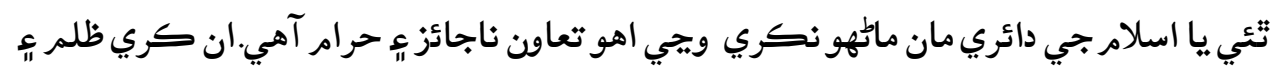

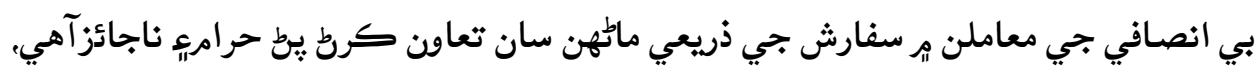

$$
\text { جيئن علام نووي فرمايو: }
$$

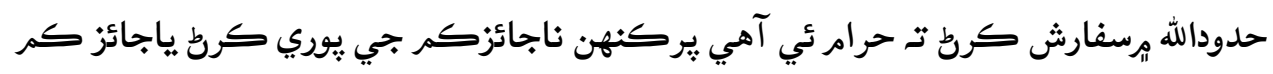

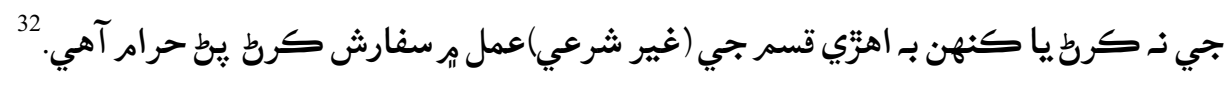

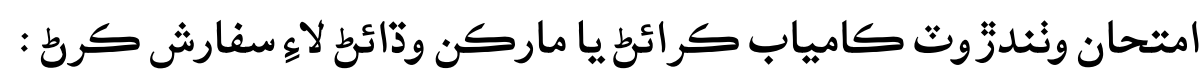

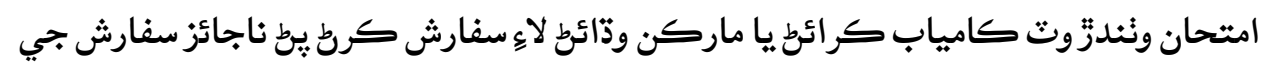

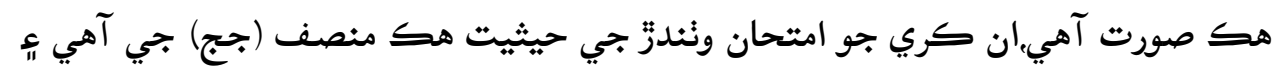

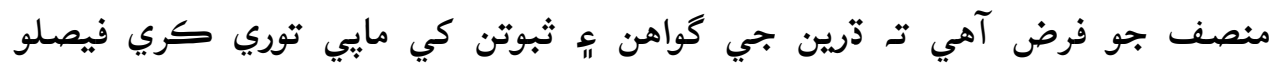

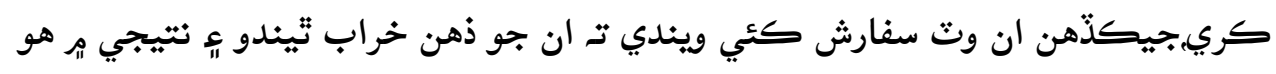


دي اسكالر ( جولائي _ جسمبر 2016 ء)

انصاف نـ كري سخهندوان كري هيءَ سفارش حقيقت يه انصاف جي راهـ ير ركاوت آهي. 33

$$
\text { سفارش هك گواهي هك مشورو: }
$$

جذهن كنهن ماطهو جي سفارش كئي ويجي تي تـ هك لحاظ سان ان جي حقدار هجط جي كواهي ذنتي ويجي تي مثنال طور:كنهن كي ملازمت ذيّارط يا ملازمت هي تر ترقي (Promotion)

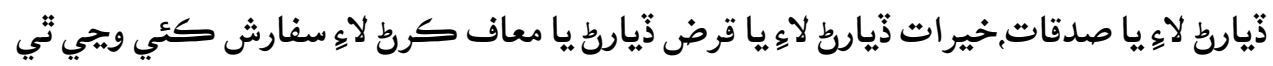

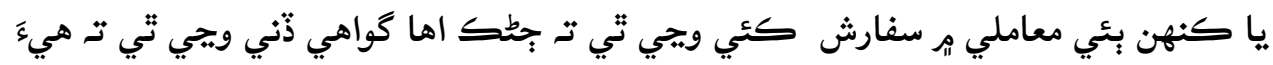
شخص انهئ شئ جوحقدار آهي جنهن لاء هن جي سفي سفارشي

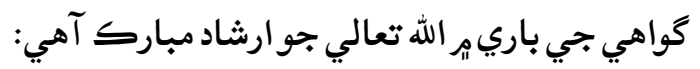

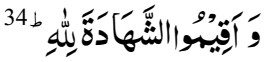
"ي الله خاطر (كنهن جي روء رعايت كانسواء )يوري يوري گواهي ذّيو."

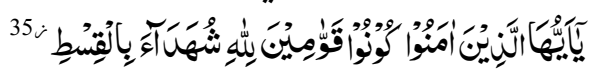

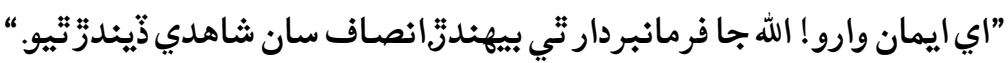

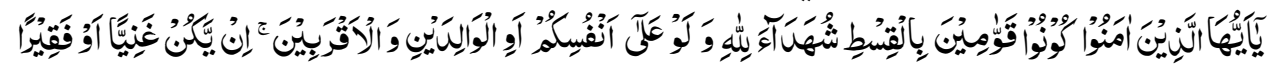

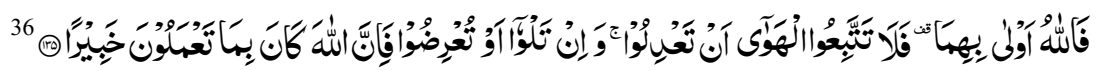
”اي ايمان وارو! انصاف تي قائم رهندزّ الله جي واسطي شاهدي ذيندزّتيو كطي (سجي شناهدي ذّيط جي كري ) توهان جو ينهنجو نقصان تئي يا توهان جي والدين جو نقصان تئئي

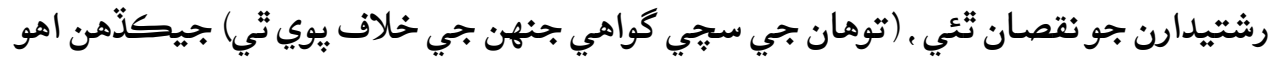

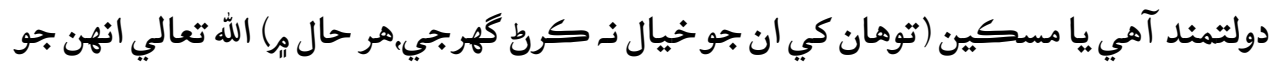

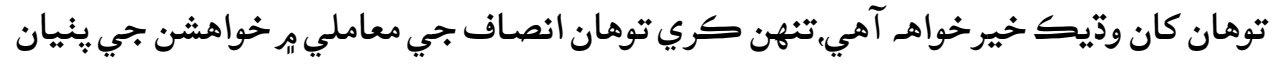

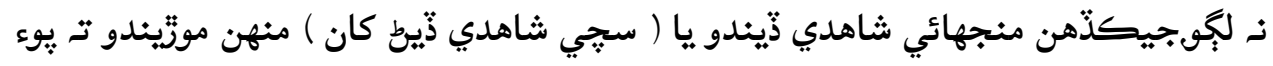

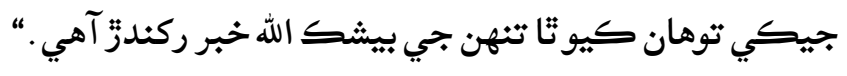
ان كري جيكذهن كنهن ناهل جي سفارش كئي وئي تـ جط كورتي كواهي ذني وئي ئ

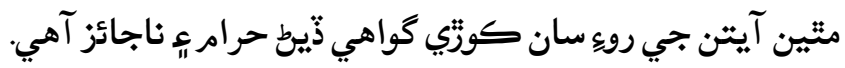

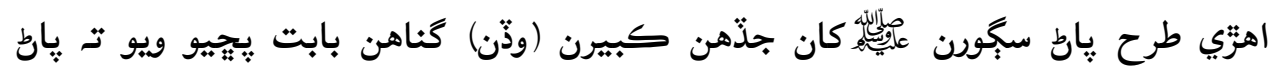

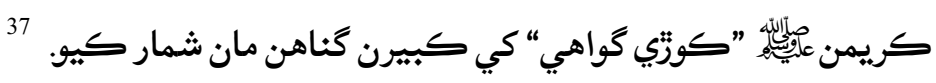
ان كري ضروري آهي تت سفارش اهل ماطهو جي كئي ويجي ، جيكذهن نا اهل جي سي سفارث

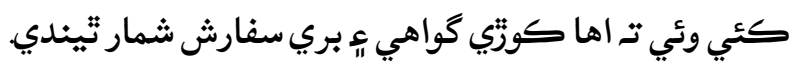


اهزي طرح سفارش هك اعتبار سان مشورو بـ آهي:جنهن شخص وت سفارش كئي

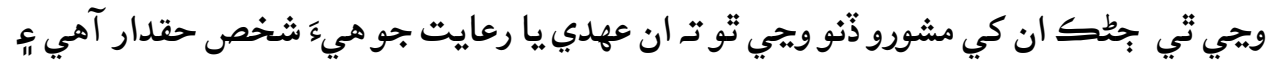

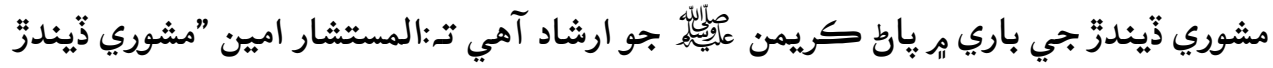
جي حيثيت امين واري آهي.،

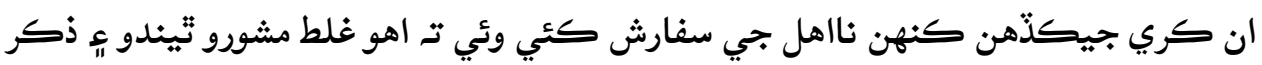

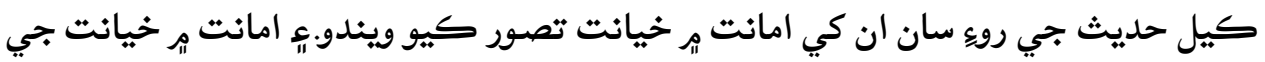

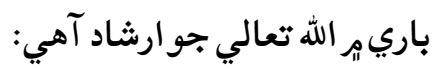

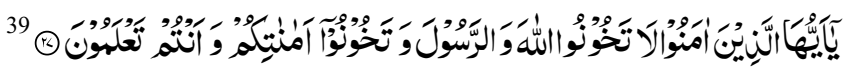

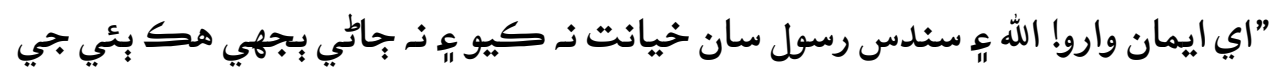

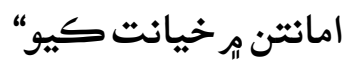

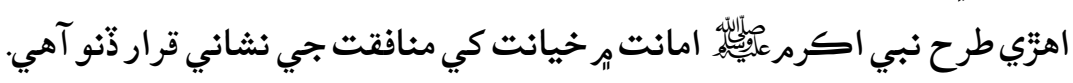

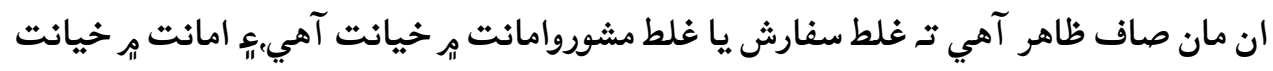
منافقت جي نثاني ئ هك كان صبيرو كناه آهي. سفارش يا مشوري تي عمل : جني

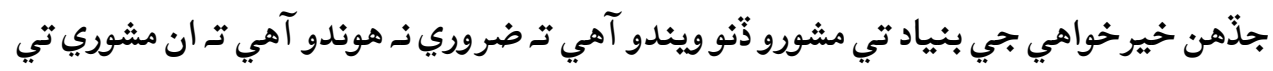

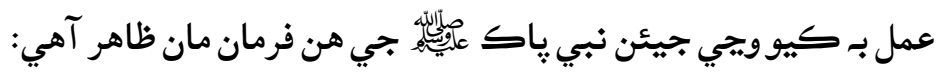

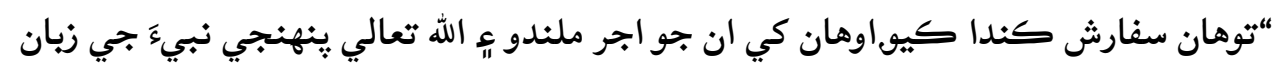

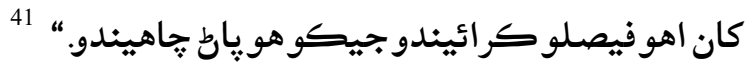

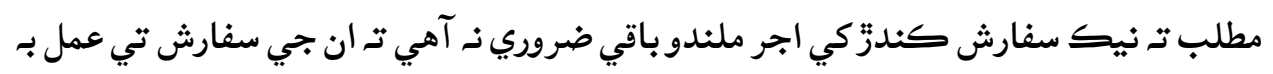

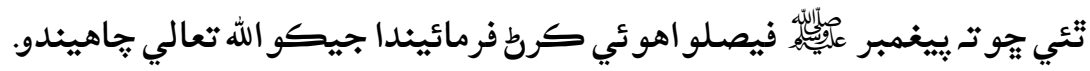

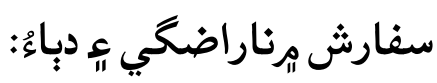

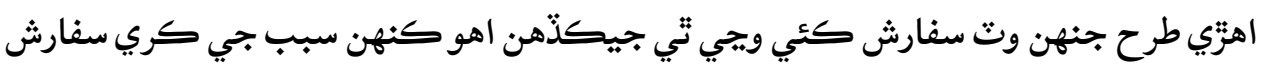

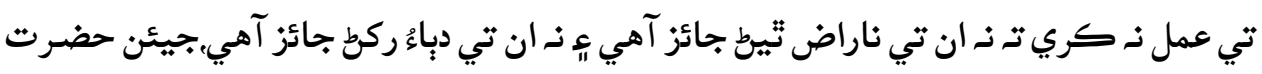

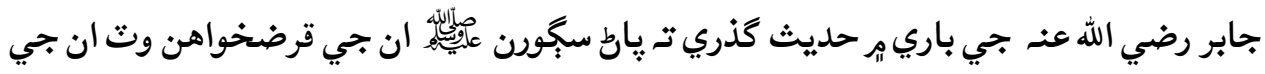

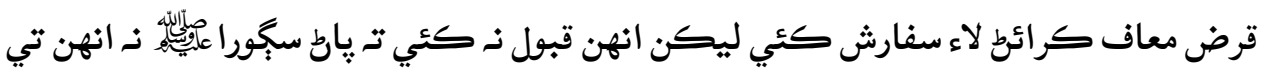

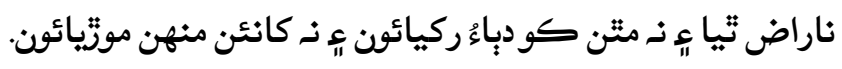

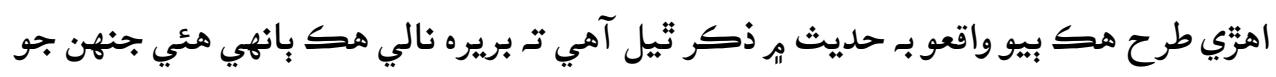


نكاح مغيث نالي هك غلام سان تيل هو. شرعي نقطئ نظر سان بانهي جي نكاح جو اختيار

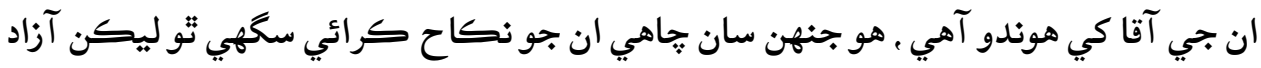

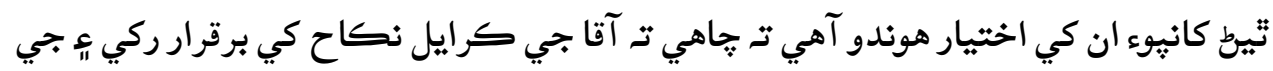

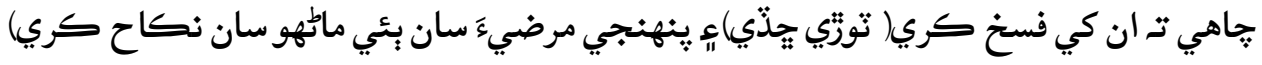

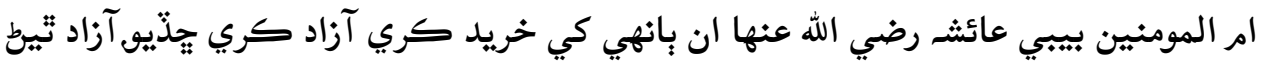

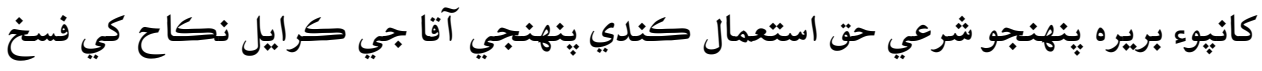

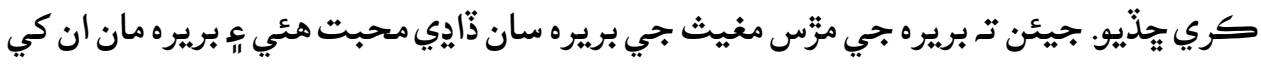

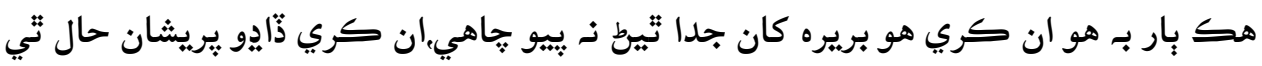

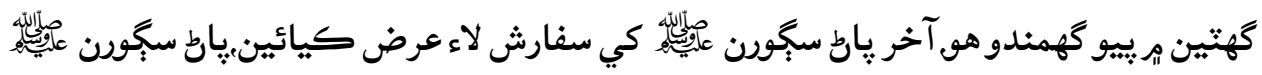

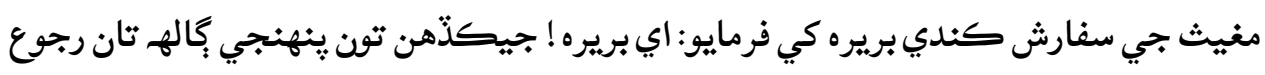

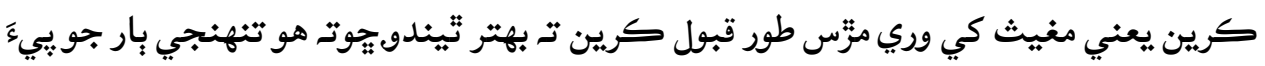

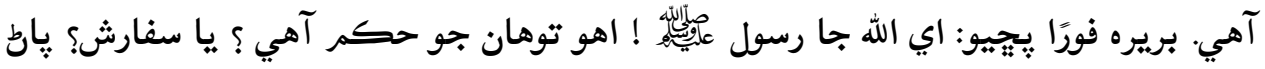

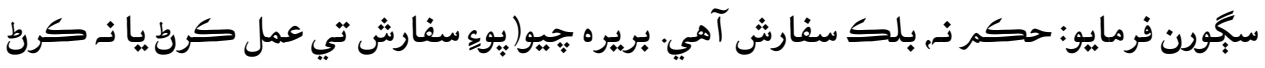

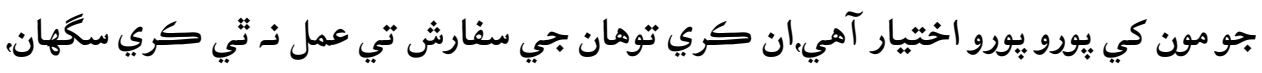

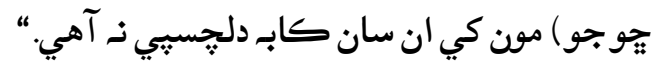

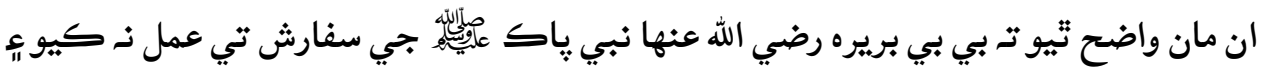

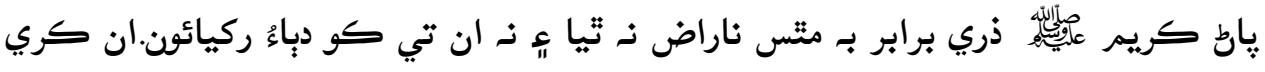

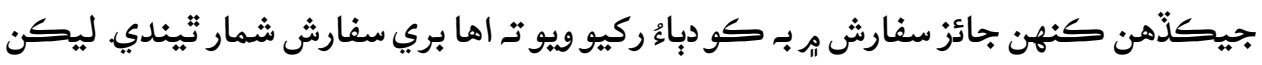

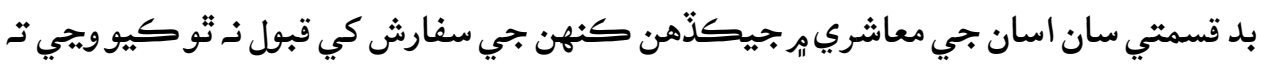

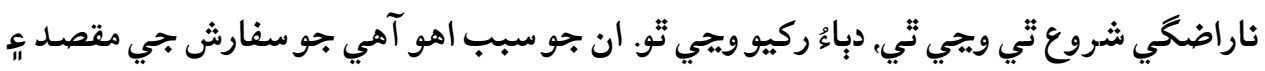

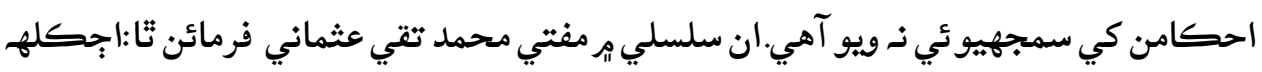

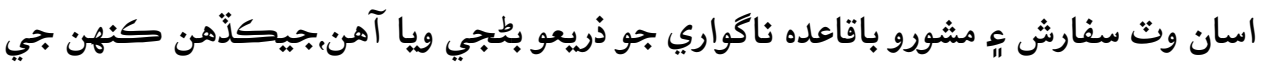

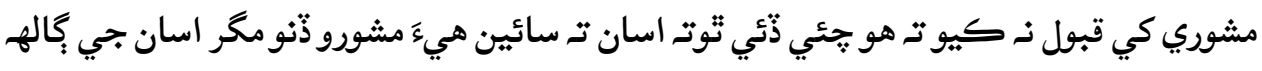

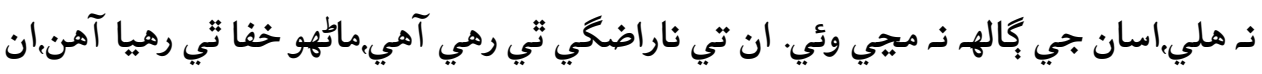

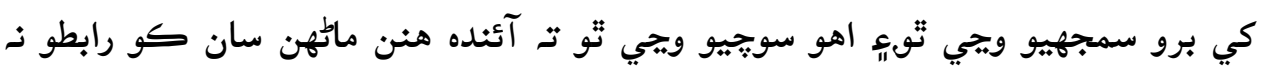

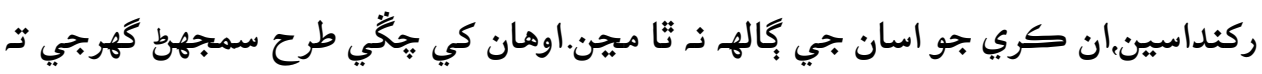

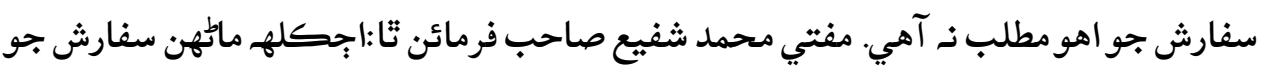

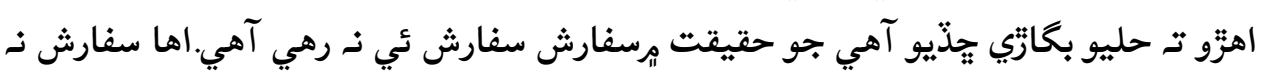




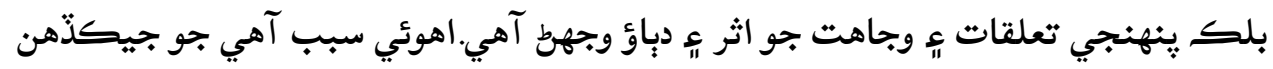

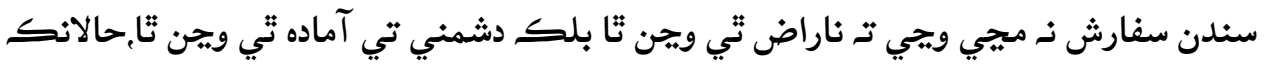
كنهن ماطهو تي اهزو دباؤوجهط جو هو ينهنجي ضمير ري مرضي جي ابتزّز كرط تي مجبور تي

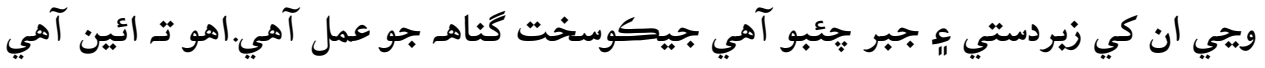
جيئن كو شخص زبردستي كنهن جي مال يا حق تي قبضو كري. آهو مانهو شرعاً ــ قانوناً

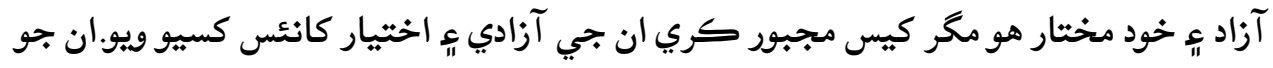

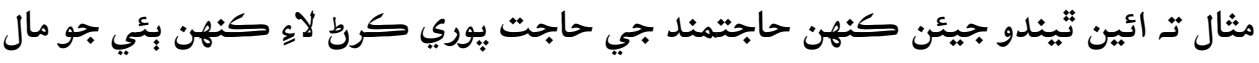
جرائي كري ان كي ذنو ويجي.

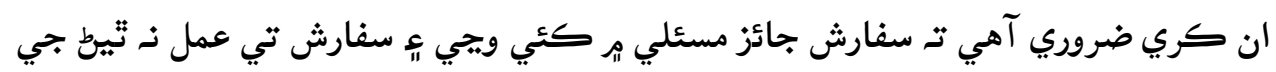

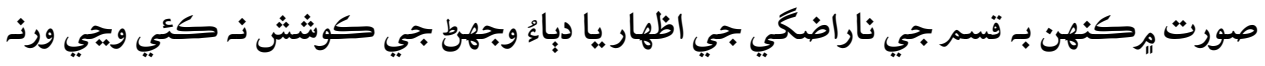

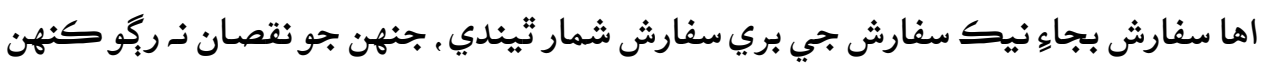

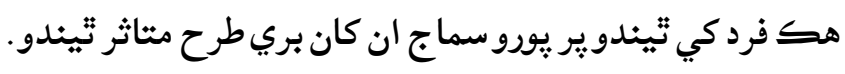
خلاصو: با اختيار اء متتدر ماطهن تائين ضرورت مند ماطهن جي ضرورتن ئ حاجتن كي يهجيائط يء انهن

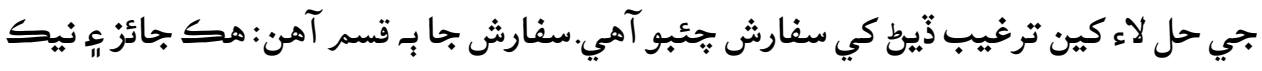

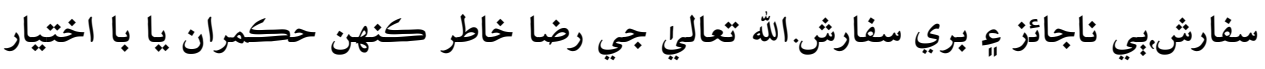
شخص كي كنهن ضرورتمند جي يارت كررط.حقدار كي سندس حق ذّيارط.مظلوم كان ظلم

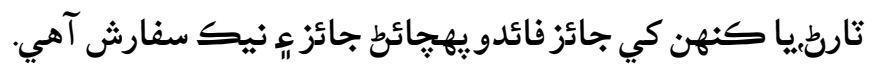

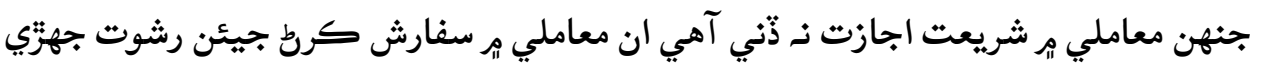

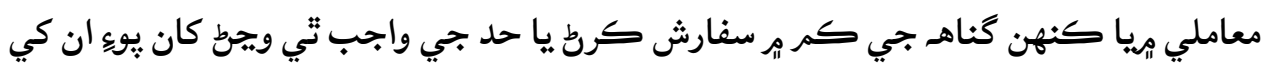
معاف كرائط لاء سفارش كرنيا كنهن ناجائزكم جي يوري كرن يا حقدار جي حق مارط

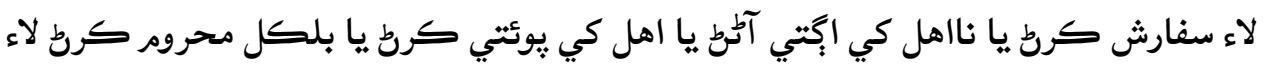

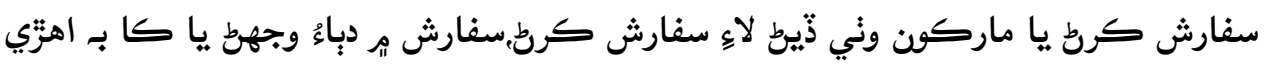

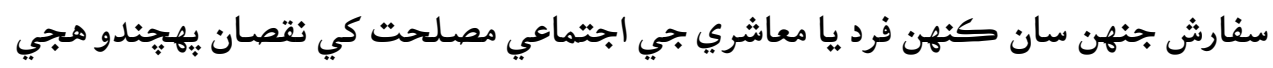

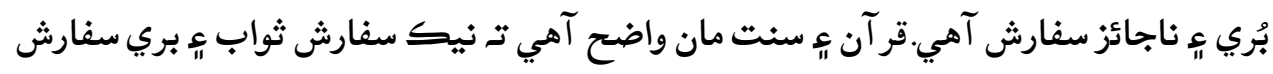


الطريقي عبد الله بن عبد المحسن. جريمة الرشوة في الثريع الاسلاميب.الرياض.المملك العربي السعوديـ، 1982ع.طبع 880.3

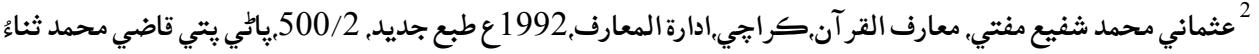

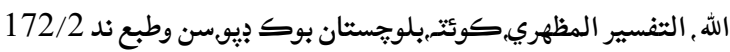

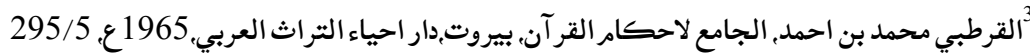
سورة النساء آيت 85 295/5 القرطبي الجامع لاحكام القرآن

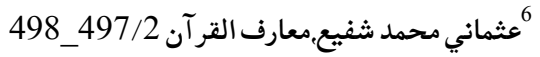

7 عثماني شبير احمد, تفسيرعثماني .مطبوعة بنفق المملكة العربية السعودية.ص 119

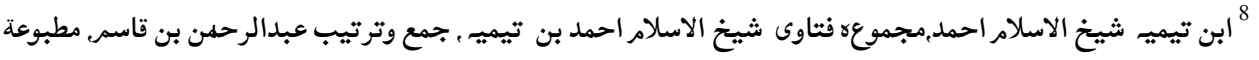

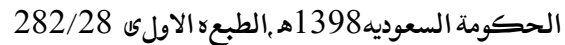

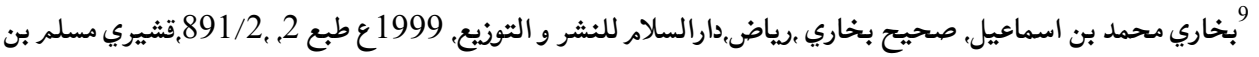

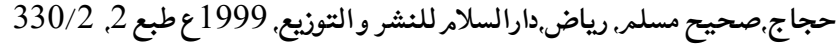
10 10

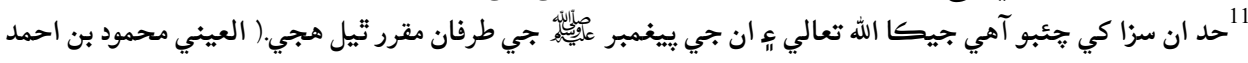

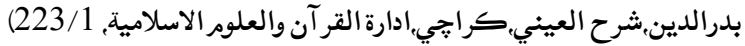

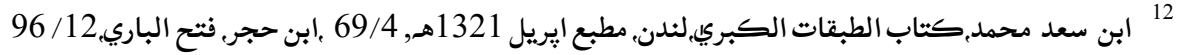
بخاري. الصحيح. 13

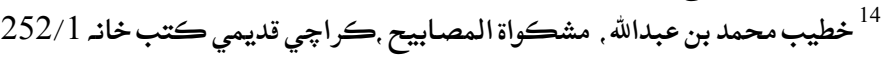
15 16 1الك بن انس اصبحي امام موءّا امار مالك.كرائي.دارالاشاعت, ص 253_264، ابن تيميـ شيخ الاسلام

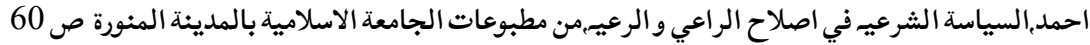

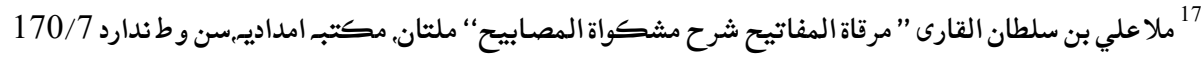

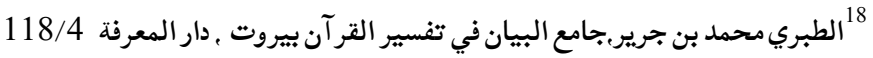
91 الطريقي. جريمة الرشوة صحمد بن 919 85 سمورة النسآ آيت 295/5 29 القرطبي. الجامع لاحكار القرآيت

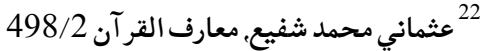

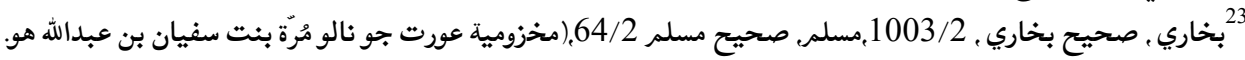

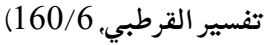
24 المنذرى عبدالعظيم بن عبدالقوى “الترغيب و الترهيب من الحديث الثريف” تحقيق سعيد محمد اللحام دار الفكر

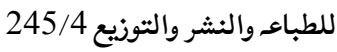
ايضًاص 247 26 ايضًاص 246 


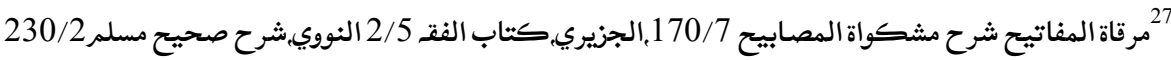
28 240 المنذري.الترغيب والترهيب آلمائ ايضان $\left.\right|^{31}$

32 32

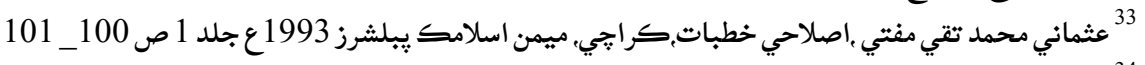
2 سورة الطلاق آيت 23 35 36 135 سوره النساء, آيت 135 64/1 38

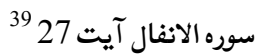
ايضا 40 41 بخاري. الصحيح 891/2، مسلم . الصحيح 330/2 42 عثماني محمد شفيع.معارف القرآن 2/ 500 